\title{
RESEARCH NOTE \\ Preparation and evaluation of pickles made from asparagus waste stems
}

\author{
Nelson Loyola, Oscar Duarte, and Carlos Acuña \\ Departamento de Ciencias Agrarias, Facultad de Ciencias Agrarias y Forestales, Universidad Católica del \\ Maule. Casilla 7-D, Curicó, Chile.
}

\begin{abstract}
N. Loyola, O. Duarte, and C. Acuña. 2012. Preparation and evaluation of pickles made from asparagus waste stems. Cien. Inv. Agr. 39(2): 361-368. The general objective of this research was to evaluate the color stability of pickled asparagus with time. The salt addition time, with respect to the color maintenance of the asparagus sprouts, and the sensory acceptability of the final products were determined in this study. Discarded asparagus stems from Longaví (Linares province), located in the central-south area of Chile, were used. The pickle preparation and sensory evaluation analysis were carried out at the Universidad Católica del Maule in Curicó, Chile. Microbiological analysis was carried out separately at a private laboratory. The pickles were prepared with three different salt concentration treatments: $2.5,7$ and $9 \%$. The sensory and microbiological attributes were evaluated after three different time periods: 10 , 11 and 12 weeks. Color, the presence of pathogenic microorganisms and the sensory attributes of flavor, texture and aroma were measured. In addition, the appearance and acceptability of the pickles was assessed by a group of thirteen trained panelists. The results of the analysis showed that it is possible to prepare pickles from asparagus stems that are waste products of the agroindustry. The panelists described variations in aroma between the $13^{\text {th }}$ and $24^{\text {th }}$ days for the treatments $2.5 \%$ and $9 \%$. However, they found that the flavor, color and appearance of all the pickles remained stable with time for all treatments. There were no significant differences in the acceptability of all the final products to determine which pickling method was the best.
\end{abstract}

Key words: Asparagus, pickles, preservation and sensory evaluation.

\section{Introduction}

The vegetable asparagus is the stem and soft sprout (also called the turion) of the plant Asparagus officinalis L. subspecies officinalis, a perennial herbaceous, monocotyledon and dioecious plant species (i.e., some plants have male flowers while

Received April 9, 2010. Accepted March 16, 2011. Corresponding author: nloyola@ucm.cl others have female flowers). The plant belongs to the Liliaceae family, along with 150 other species (Del Pozo and González, 1999).

This species originated in the ancient region of Mesopotamia and extended to Egypt, Greece and Italy. Arabs introduced asparagus to Spain in the $13^{\text {th }}$ century. It is currently commercialized in at least 61 countries, with an estimated total crop area of 253,455 ha (Benson, 2002). The 
main global producers are China, Peru, United States, Japan and Mexico. In Europe, the main producers are Spain, Germany, Greece, France and Italy; all combined produce an equivalent to Chinese production (the main producer in the world) (Anonimous, 2007).

In Chile, the cultivated surface area is approximately 4,100 ha (ODEPA, 2007), distributed between the $\mathrm{V}$ and $\mathrm{X}$ regions, where most of the plantations are in zones with a Mediterranean climate (i.e., cold and rainy winters, warm and humid springs, hot and dry summers), although they may adapt to desertic, marine and cold temperate climates, among others (Del Pozo and González, 1999).

Asparagus is a good source of minerals, vitamins, amino acids and fiber. Additionally, the stems are rich in antioxidants and phenols (flavonoids) (Shou et al., 2007); therefore, asparagus has been considered a luxury product. Due to the short harvest period and availability of fresh asparagus, it is processed in every possible way to satisfy demand: canned, frozen, dehydrated, juiced, and pickled. Krarup and Contreras (2002) tested fresh green asparagus considered for export and found that between $50 \%$ and $80 \%$ were classified as waste products. Therefore, preservation methods such as pickling could be a good alternative for both domestic and international markets.

The pickling method consists of the preservation of asparagus in a brined medium, where fermentation processes may occur. Fermentation transforms carbohydrates. Organic acids comprise $5 \%$ of the stem; in this case, lactic acid.

The main factor controlling pickling, fermentation and acidified product production is acidity, or the low $\mathrm{pH}$ of the medium. The $\mathrm{pH}$ decrease in the medium may be achieved by natural acidification, as the result of a fermentation process with bacteria producing lactic acid. Depending on the type of product, the process may take hours to several months. The successive growth of different species of lactic bacteria occurs during fermentation in anaerobic conditions, causing a final concentration of lactic acid in the medium of $1 \%$ weight/weight (Fellows, 1994).

Medium acidification may also be achieved by the addition of organic acids, such as lactic, citric and acetic acids. Acetic acids are most commonly used in industrial processes.

Pickles may be prepared without fermentation or with total or partial fermentation; in the last two cases, they may be pasteurized to improve the quality of the product (Frazier and Westhoff, 1993). As there are few alternative uses for asparagus stems discarded in the agroindustry, farmers could potentially process the waste to produce added value products such as pickles.

This study aimed to evaluate the color of asparagus pickles as a function of salt concentration and time. The acceptability of the final product was also determined through sensory analysis.

\section{Materials and methods}

Pickling of the asparagus stems was carried out in the Universidad Católica del Maule in Curicó, Chile. Healthy discarded stems, those that did not fulfill the size requirements for export as fresh or frozen products, were used (minimum length: 18 $\mathrm{cm}$, minimum diameter: $6 \mathrm{~mm}$ ). The stems were donated by Mr. Manuel Espinoza from the San Manuel plot in Longaví (35 $55^{`}$ South latitude and $71^{\circ} 33^{\prime}$ West longitude).

A control treatment and two pickling treatments each required $3.6 \mathrm{~kg}$ of asparagus pieces between 3 and $4 \mathrm{~cm}$ long. The control treatment with $2.5 \%$ salt had a brine solution with a constant concentration of $2.5 \%$. The other two treatments had initial brine solutions of 7 and $9 \%$ that were gradually augmented one percent every 10 days, until reaching up to 15 to $16 \%$ of brine. Three measurements of salt concentration were taken at various times during the treatments, as shown in Table 1. Only common salt was used as an additive in the treatments. 
The stems were first submerged in a solution with $200 \mathrm{ppm}$ of chlorine. Then, they were cut into Cut and Tips pieces (the trunk and head of the stem). After cutting, the stems were blanched for 45 seconds at a temperature of $60{ }^{\circ} \mathrm{C}$ then immediately placed in cold water. A total of $10.8 \mathrm{~kg}$ of asparagus pieces were placed in a $40 \mathrm{~L}$ plastic container containing an $80.2^{\circ} \mathrm{Brix}$ corn syrup solution ( $935 \mathrm{~mL}$ in $10 \mathrm{~L}^{-1}$ of water) for 5 hours to increase the sugars available for fermentation. After that period, the stems were divided among three plastic containers, each with a capacity of approximately $40 \mathrm{~L}$; approximately $3.6 \mathrm{~kg}$ of asparagus were placed in $6 \mathrm{~L}$ of water for each of three treatments. Salt was then added to the containers; 270, 756 and $972 \mathrm{~g}$ of salt were added 2.5, 7 and 9\%, respectively (Figure 1). The exposed brine surface in each container was covered with a plastic sheet and water was added on top of it to keep the sheet in place and prevent exposure of the pieces, guaranteeing the seal and the fermentation process. To evaluate the progress of the fermentation process and to adjust the chlorides concentration according to the corresponding increase for each stage, the containers were covered and the lactic acidity and the concentration of sodium chloride was measured every 10 days on average.

The $\mathrm{pH}$ of samples taken from each container was measured with a pH meter Hanna, model HI8424 located at the chemistry lab in the Universidad Católica del Maule in Curicó, Chile. The lactic acidity was measured by titration with sodium hydroxide $0.1 \mathrm{~N}$, while the concentration of chlorides was measured by titration with silver nitrate $0,1 \mathrm{~N}$, according to the procedure outlined by the laboratory of Tecnología de Productos Hortofrutícolas (Acuña, 2006. Profesor Universidad Católica del Maule. Curicó, Chile, personal communication). The samples were taken at the different brine concentrations (Table 1).

Table 1. Salt concentration of the samples before packaging.

\begin{tabular}{lccc}
\hline Days after preparation & $2.5 \%$ initial salt (\%) & $7 \%$ initial salt (\%) & $9 \%$ initial salt (\%) \\
\hline 13 & 2.7 & 13.7 & 15.3 \\
20 & 2.42 & 14.9 & 15.6 \\
24 & 2.62 & 15.6 & 16.0 \\
\hline
\end{tabular}

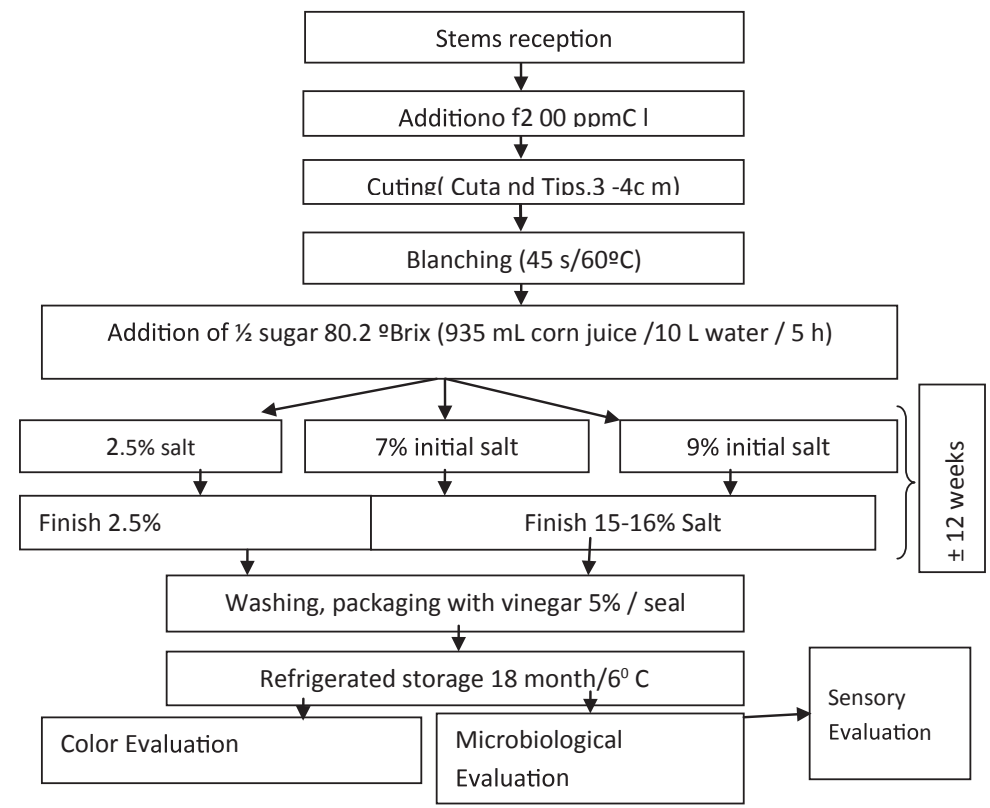

Figure 1. Flow chart for the preparation of pickles and evaluation. 
After the pieces were removed from the pickling container, their $\mathrm{pH}$, lactic acid and chloride content were measured. They were then washed with water at a temperature between 50 and $60^{\circ} \mathrm{C}$ to a salt concentration of $4 \%$, which was measured by titration. Subsequently, the pieces were placed in $200 \mathrm{~mL}$ jars in a packing medium blanched at $2.0 \%$, with a $5 \%$ solution of white wine vinegar. The jars contained $60 \%$ asparagus and $40 \%$ packing medium and were stored for 18 months. The color of the pickles was evaluated at the laboratories of quality control of Empresa Agrozzi in the province of Curicó. A Colorflex 1226 colorimeter was used. The stems pieces from 9 jars were grounded up, forming a paste, for the colorimeter evaluation.

The colorimeter works according to the theory of opposed colors, which assumes that the receptors in the human eye perceive colors in opposed pairs, i.e., light-darkness, red-green and yellow-blue. The data were provided through three parameters: 1) luminosity (L), which ranges between 0 (total darkness or black) and 100 (total luminosity or white); $\mathrm{a}^{*}$, which ranges from negative values $\left(-\mathrm{a}^{*}\right)$ that correspond to green intensities to positive values ( $\mathrm{a}^{*}$ ) that correspond to red tones; and $\mathrm{b}^{*}$ values that range from negative values (blue) to positive values (yellow) (Hunterlab, 2008).

The microbiological analysis was performed at Quality Lab., located in Curicó. The count analyses for potential aerobic mesophile contaminants (ufc $\mathrm{g}^{-1}$ ), fungi (ufc g-1), yeasts (ufc g-1) and Escherichia coli $\left(\mathrm{PNM} \mathrm{g}^{-1}\right)$, were carried out according to the methodology of the Chilean standards NCh 2659 Of.2002, NCh 2734 Of.2002 and NCh 2636 Of.2001 (INN, 2008). Nine samples corresponding to each treatment were analyzed. According to the Chilean standards indicated, the four analyses provided negative results for all the samples, which allowed for the last stage of evaluation.

The sensory evaluation was conducted at the laboratory of sciences of Universidad Católica del Maule in Curicó, where cubicles were fully equipped for the evaluation of the different samples and the elimination of distractive agents that might alter each tasting. Bread, water and coffee were supplied; the bread and water were consumed in between samples to block the sensation of flavor and texture of the previous sample while the coffee aroma was inhaled in between each sample. Evaluation notepads were provided, where the panelists recorded the sensations and identified each attribute evaluated (Stone and Sidel, 1993). There were two types of notepads, unstructured and structured. The first type was adapted to determine if the panelists (13 judges) could identify attributes, such as aroma, texture and flavor. It required a line to be traced perpendicularly to a $13 \mathrm{~cm}$-horizontal axis that faced each attribute, according to the sensation perceived. The structured notepads were adapted to identify the opinions of the judges with regards to the appearance, color and acceptability of each sample; the panelists provided scores for each sample (Witting, 1990). The experimental design used was based on a 2-factor model (pickling time, and initial brine concentrations) with 3 levels for each factor (13, 20 and 24 days after pickling; initial brine concentrations of 2.5, 7.0 and 9.0\%) and 4 repetitions. Analysis of variance (ANDEVA) and the Tukey test were used when there was a difference between means, with $\mathrm{P} \leq 0.05$. The results were entered into the statistical program XLSTAT (2007).

\section{Results and discussion}

\section{Perception of aroma}

Significant differences between treatments with $2.5 \%$ salt at 13 days of pickling, $9 \%$ at 20 and 24 days of pickling, and $2.5 \%$ after 24 days of pickling, were determined after analyzing the effects of the factors (pickling time and brine concentration) on the aroma of the products (Figure 2). According to Lau and Tang (2002), pasteurization could avoid changes in aroma, color and texture and was used in this test. 


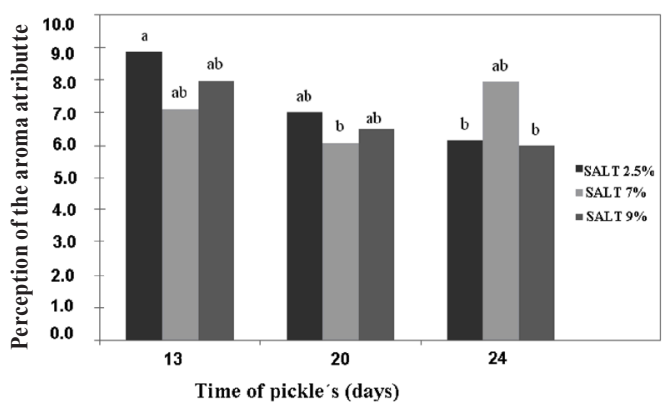

Figure 2. Perception of the aroma attribute and the interaction between pickling time and the initial salt concentration $(2.5 \%, 7 \%$ and $9 \%)$. Average values without letters do not have significant differences, according to the Tukey test at $0.05 \%$.

\section{Perception of texture}

Most of the mechanical changes observed in the stems were made during the preparation, especially during cooking, according to Rodriguez-Arcos et al. (2002). Therefore, pickles with an appropriate salt concentration may minimize these changes and provide a more homogeneous product in terms of texture and color.

The panelists perceived the texture of stems from treatment with $2.5 \%$ salt as better in comparison to $7 \%$ salt after 13 days of pickling. This perception was balanced after 20 and 24 days of pickling, and the stems from treatment $7 \%$ salt had better values at day 24 , which is associated with a higher salt gradient in comparison to the final pickles concentration of $15 \%$ to $16 \%$. Treatment with $9 \%$ salt had a lower gradient, which was close to the final concentration recommended, in the first measurement, due to the degree of stabilization (Figure 3). According to Cheftel et al. (2000), low salt concentrations, close to $2 \%$, do not inhibit the proliferation of cellulitic or pectinolytic organisms, which generate soft products. In this study, the texture evaluations provided by the judges for the stems of treatment with $2.5 \%$ salt decreased as time passed (Rodriguez et al. 2004). Authors such as Paphangkorakit et al. (2006) have studied the chewing easiness or difficulty of some fibrous foods such as asparagus; therefore, pickling is a mechanism that may substantially change the percep-

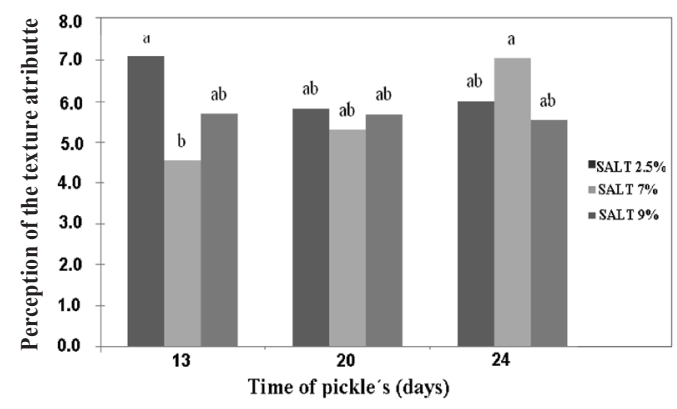

Figure 3. Perception of the texture attribute and the interaction between pickling time and the initial salt concentration $(2.5 \%, 7 \%$ and $9 \%)$. *Average values without letters do not have significant differences, according to the Tukey test at $0.05 \%$.

tion of the stems' texture as they are consumed, in comparison to the fresh product. Perez et al. (2002) predicted the degree of the stems' texture for fresh consumption, which may be useful as a metric to maintain uniform raw material for agroindustry.

\section{Perception of flavor}

The data shows that the panelists rated the flavor of all the pickles similarly and stably with time, which is reflected in the statistical analysis (Figure 4).

\section{Appearance}

The analysis of the appearance evaluations recorded by the judges indicated no significant differences among the different treatments at different pickling times, in comparison to the control or the interaction between both factors. Therefore, we may infer that none of the methods used altered the appearance of the product, which was maintained until the last observation at 24 days of pickling. This is in agreement with the results of Cheftel et al. (2000) in regards to the maintenance of the products in brines close to $2 \%$, as previously mentioned. Thus, pickled asparagus can maintain features similar to minimally processed products that are subsequently placed in frozen storage (Albanese, 2007). 


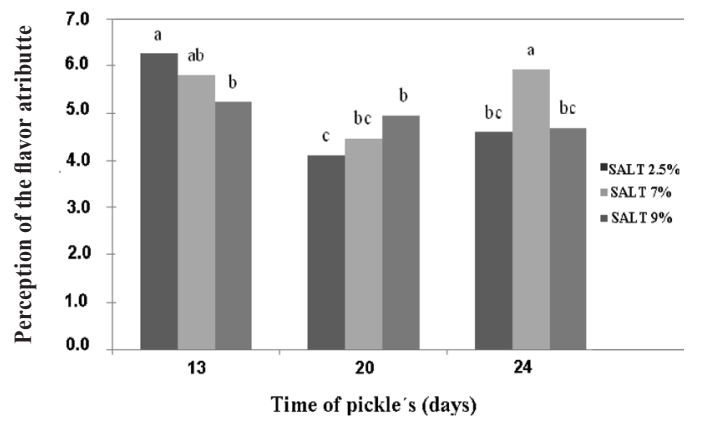

Figure 4. Perception of the flavor attribute and the interaction between pickling and initial salt concentration $(2.5 \%, 7 \%$ and $9 \%)$. *Average values without letters do not have significant differences, according to the Tukey test at $0.05 \%$.

\section{Perception of color}

The analysis of the color evaluations recorded by the panelists showed no significant differences in color among the different treatments at different pickling times when compared to the control. Even the interaction between both factors had no effect on the color of the samples. Therefore, we may infer that none of the methods used altered the product color, which was maintained until the last observation at 24 days of pickling. We assume that the short asparagus blanching for 45 seconds fixed the color, maintaining a tone ranging between dark green and green in all the treatments, as described by the panelists. This is supported by the work of Lau et al. (2000), who indicated that the exposure of the stems to high temperatures in processes such as blanching, may affect their color and texture at excessive times of exposure.

\section{Acceptability}

The analysis of the panelists' evaluations for the acceptability of pickled asparagus stems indicated the absence of any significant differences among the different brine treatments at different pickling times in comparison to the control. The interaction between both factors did not have an effect either.

\section{Pickles color}

Instrumental color measurement was used to complement the sensory analysis carried out by the panelists; therefore, a more objective quantification of the treatments could be obtained. Each of the parameters measured are discussed in the following subsections.

Evaluation of luminosity " $L$ ". The value of $L$ was numerically different for each brine concentration of the study, although there was a similarity in the data provided by the instrument for the three treatments at different pickling times. The pickles that exhibited the best luminosity were from treatment with $2.5 \%$ salt at 13 and 20 days of pickling; the other two treatments showed similar results. Thus, we may infer that although the level of blanching provided a slight turbidity to the pickling solution, the differences in luminosity among the pickled stems was minimal, only a 4 point difference existed between the samples (Figure 5).

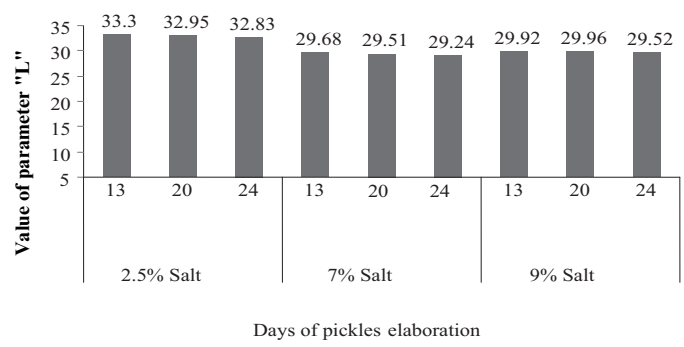

Figure 5. Average values measured for the parameter $L$ (Bright) from the samples of pickles of asparagus with the different treatments.

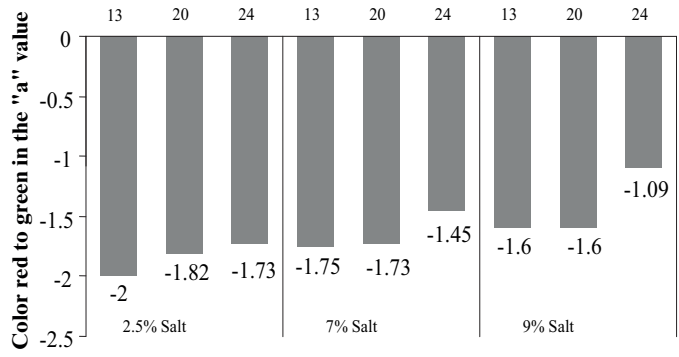

Figure 6. Average values measured for the parameter " $a$ *" (red - green) from the samples of pickles of asparagus with the different treatments. 
Evaluation of parameter " $a$ *". The negative $\mathrm{a}^{*}$ values measured by the photocolorimeter indicated green tones $\left(-\mathrm{a}^{*}\right)$, whereas the magnitude of the value indicated the tone intensity. As observed in Figure 6, treatment with $2.5 \%$ salt reflected tones slightly greater than the pickled stems of the other treatments. As inferred in the case of luminosity, brine concentration may also have been the cause of these differences in tones in the pickles stems.

Evaluation of parameter " $b$ *”. Positive values of this parameter are related to the intensity of the yellow color. Minimal differences were observed between the samples of all the treatments (values ranged between 11.6 and 11.13). The highest values were obtained by samples of treatment with $2.5 \%$ in comparison to yellow tones of the. The measurements allowed for grading from dark green to light green. According to the results of this research, we conclude that the preparation of pickles from discarded asparagus stems that are free from pathogens is feasible; a product with good aroma, flavor and color can be obtained.

The treatment with $7 \%$ salt at 13 days provided the most adequate method for maintaining the stems' color because it showed the highest green tones, as determined by the photocolorimeter.

The sensory panelists identified variations in the aroma of samples pickled for 13 and 24 days, particularly in treatments with $2.5 \%$ and $9 \%$ salt. In regards to the flavor, color and appearance, the panelists perceived the pickles similarly and rather stably with time, regardless of the treatment applied. In regards to the degree of acceptability of the finished product, there was no significant difference to determine which method produced the best pickles.

\title{
Resumen
}

\begin{abstract}
N. Loyola, O. Duarte y C.Acuña. 2012. Elaboración y evaluación de encurtido de espárragos provenientes del descarte en la agroindustria. Cien. Inv. Agr. 39(2): 361-368. El objetivo general de la presente investigación fue elaborar encurtidos de espárragos, manteniendo el color verde obteniendo un producto aceptable, determinar el método de elaboración de encurtido para turiones de espárragos, tiempos de adición de sal, apropiados para mantener el color y lograr la aceptabilidad del producto final, utilizando análisis de evaluación sensorial. Los turiones de espárragos (Asparagus officinalis L. subespecie officinalis) fueron adquiridos en Longaví, provincia de Linares, elaborados y analizados sus aspectos sensoriales en la Universidad

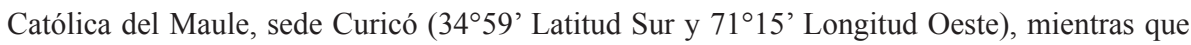
los análisis microbiológicos se realizaron en un laboratorio certificado externo. Los pickles fueron elaborados en tres diferentes concentraciones de sal, siendo los tratamientos: 2,5, 7 y $9 \%$. Se realizó una evaluación sensorial y microbiológica en tres diferentes tiempos: a las 10, 11 y 12 semanas. Los atributos sensoriales fueron: color, sabor, textura y aroma, siendo evaluada también la presencia de microorganismos patógenos. Adicionalmente, se midió la aceptabilidad y apariencia de los pickles con un grupo de trece panelistas entrenados. Los resultados de los análisis determinaron que es posible la elaboración de encurtidos libre de patógenos, a partir de turiones de descarte de la agroindustria. Los panelistas identificaron que hubo variaciones en el aroma entre los 13 y 24 días, particularmente con los tratamientos con $2,5 \%$ y $9 \%$ de concentración de sal. Respecto al sabor, color y apariencia, los panelistas percibieron a los pickles de forma similar y estable a través del tiempo, independiente del tratamiento aplicado. Con respecto al grado de aceptabilidad del producto terminado, tampoco existió diferencia significativa para identificar el mejor método, indistintamente del método empleado.
\end{abstract}

Palabras clave: Conservación, encurtido, espárragos, evaluación sensorial. 


\section{References}

Albanese, D., L. Russo, and L. Cinquanta. 2007. Physical and chemical changes in minimally processed green asparagus during cold-storage. Food Chemistry 101: 274-280.

Anónimo. 2007. Alimentación sana. Novedades. Available online at: http:/www.alimentacionsana.com.ar/Informaciones/novedades/espárragos. htm (Website accessed July 12, 2007).

Benson, B. 2002. Update of the world's asparagus production areas, spear utilization and production periods. International society for horticultural science. ISHS. Acta Horticulturae 589: X International Asparagus Symposium. Available online at: <http:/www.actahort.org/members/ showpdf booknrarnr $=589$ _3 $>$ (Website accessed: March 16, 2008).

Cheftel, J., H. Cheftel, and P. Besançon. 2000. Introducción a la bioquímica y tecnología de los alimentos. Volumen II. Editorial Acribia S.A. Zaragoza. España. 404 pp.

Del Pozo, A., and M. González. 1999. El cultivo del espárrago. Boletín Instituto Nacional de Investigación Agropecuaria (INIA) No 6. Ministerio de Agricultura. Chile. 212 pp.

Fellows, P. 1994. Tecnología y procesado de los alimentos: Principios y prácticas. Editorial Acribia S. A. Zaragoza, España. 549 pp.

Frazier, W. and D. Westhoff. 1993. Microbiología de los alimentos. Edición 4. Editorial Acribia S.A. Zaragoza, España. 681 pp.

HunterLab. 2008. Aplications note. Insight of color. Vol. 13. No2. Available online at: http://www. hunterlab.com/Instruments/Bench/ColorFlex (Website accessed: June 8, 2008).

INN. 2008. Normas chilenas para elaboración de encurtidos; NCh 2659, of. 2002; NCh 2734, of. 2002; NCh 2636, 2001. Instituto Nacional de Normalización (INN). Available online at: http:// www.inn.cl (Website accessed: August 2, 2008).

Krarup, C., and S. Contreras. 2002. Elongación y ramificación de turiones de espárrago durante una cosecha primaveral. Agricultura Técnica 62: 191-200.

Lau, M.H., J. Tang, and B.G. Swanson. 2000. Kinetics of textural and colour changes in green asparagus during thermal treatments. Journal of Food Engineering 45: 231-236.

Lau, M.H., and J. Tang. 2002. Pasteurization of pickled asparagus using $915 \mathrm{MHz}$ microwaves. Journal of Food Engineering 51: 283-290.

ODEPA. 2007. Estadísticas de la agricultura chilena, considerando zonas de producción y especies. Available online at: http://www.odepa.cl Website accessed: August 2, 2007).

Paphangkorakit, J., N. Thothongkam, and N. Supanont. 2006. Chewing-side determination of three food textures. Journal of Oral Rehabilitation 33: 2-7.

Perez D., M.T. Sanchez, and G. Cano. 2002. Prediction of texture in green asparagus by near infrared spectroscopy (NIRS). Journal of Food Quality $25: 277-287$.

Rodriguez-Arcos, R.C., A.C. Smith, and K.W. Waldron. 2002. Mechanical properties of green asparagus. Journal of the Science of Food and Agriculture 82: 293-300.

Rodriguez, R., S. Jaramillo, and A. Heredia. 2004. Mechanical properties of white and green asparagus: changes related to modifications of cell wall components. Journal of the Science of Food and Agriculture 84: 1478-1486.

Shou, S., G. Lu, and X. Huang. 2007. Seasonal variations in nutritional components of green asparagus using the mother fern cultivation. Scientia Horticulturae 112: 251-257.

Stone, H., and J. Sidel. 1993. Sensory evaluation practices. Second edition. Academic Press, NYC. 53 pp.

XLSTAT. 2007. Tutorial XLSTAT version 7.5. Available online at: http:/www.xlstat.com (Website accessed: March 1, 2007).

Witting, E. 1990. Metodología de evaluación sensorial. Facultad de Ciencias Químicas y Farmacéuticas. Universidad de Chile. Santiago, Chile. 302 pp. 